\title{
NOTE
}

\section{MATING BEHAVIOR OF PATAGONIAN OCTOPUS (Octopus tehuelchus) UNDER LABORATORY CONDITIONS}

\author{
Mercedes Berrueta $^{1}$, Julián A. Desiderio ${ }^{1}$, Florencia Agliano ${ }^{2}$, Andrea Victoria López ${ }^{1}$, \\ Eddie O. Aristizabal Abud ${ }^{1,2}$ and Nicolás Ortiz ${ }^{3}$ \\ ${ }^{1}$ Instituto Nacional de Investigación y Desarrollo Pesquero (INIDEP), \\ Paseo Victoria Ocampo No 1, Escollera Norte, B7602HSA - Mar del Plata, Argentina \\ e-mail: mberrueta@inidep.edu.ar \\ ${ }^{2}$ Departamento de Ciencias Marinas, Facultad de Ciencias Exactas y Naturales, Universidad \\ Nacional de Mar del Plata (UNMdP), Funes 3350, B7602AYL - Mar del Plata, Argentina \\ ${ }^{3}$ Laboratorio de Cefalópodos, Instituto de Biología de Organismos Marinos \\ (IBIOMAR-CONICET), Blvd. Brown 2915, U9120ACD - Puerto Madryn, Argentina
}

\begin{abstract}
Patagonian octopus (Octopus tehuelchus) is a species that holds an artisanal fishery in the northern area of the Argentine Patagonian coast and has a potential for aquaculture development. This work aimed to characterize the mating behavior of four pairs of Patagonian octopuses under laboratory conditions. Results showed that this species has a complex reproductive behavior. Remarkably, female remained inside her shelter during pre-copula, copulation and intercourse events. Male and female faced by the oral face during sexual intercourse, which lasted 3 to 5 min. The observations will contribute to the better management of the reproductive specimens of the species in captivity.
\end{abstract}

Key words: Octopus tehuelchus, aquaculture, copula, hectocotyle.

Mating in cephalopods has been analyzed in the natural environment (Boletzky and Hanlon 1983) as well as in the laboratory (Wood et al. 1998; Gutiérrez et al. 2012), observing complex behaviors between male and female during courtship (pre-copulation) and copulation (Huffard et al. 2008). This complexity has consequences at the individual, population and productive systems levels (Sims et al. 2001). In addition, marked separation by age, size or proportion of individuals during reproduction in different octopus species have been described (Sims et al. 2001).

Patagonian octopus Octopus tehuelchus (Orbigny, 1834) (Cephalopoda: Octopodidae) is an endemic, semelparous, small-sized species $(<150 \mathrm{~g})$ inhabiting the Southwestern Atlantic
Ocean, from south of Brazil $\left(16^{\circ} \mathrm{S}\right)$ to the northern part of the Argentine Patagonia $\left(44^{\circ} \mathrm{S}\right)$. It is found in rocky substrates from low intertidal to the shallow subtidal zone, up to $100 \mathrm{~m}$ depth (Iribarne 1991; Ré 1998; Narvarte et al. 2006; Storero et al. 2010; Ré and Ortiz 2011) (Figure 1). Females fix egg clutches to a hard substrate, usually a hole in the rock, empty shells or artificial shelters. In this way, embryos are safe from predators, oxygen level is high by fanning water currents, and incubation area is free from dead embryos and debris (Ré 1998). This species is caught by an artisanal fishery community in the northern Patagonian coast of Argentina (Iribane 1991; Ré 1998; Narvarte et al. 2006) and it has been the subject of biological and fishery studies in the last decades 


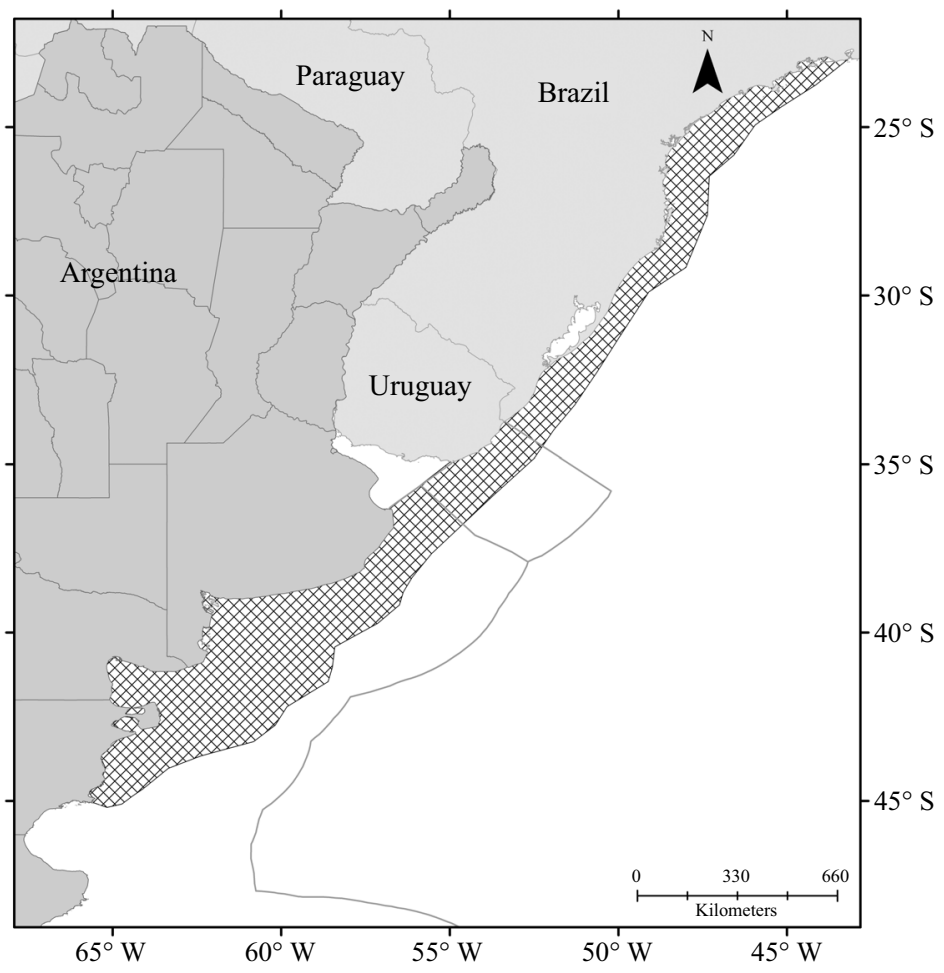

Figure 1. Geographic distribution of Octopus tehuelchus in the Southestern Atlantic Ocean (Ré 1998, 2008).

(Pujals 1982; Narvarte et al. 1996, 2007; Storero et al. 2012; Fassiano et al. 2017). Recently $O$. tehuelchus has been considered as a potential aquaculture resource (Berrueta et al. 2018a, $2018 \mathrm{~b}$ ), but the lack of understanding of some aspects of reproductive behavior useful for developing an incubation plant, hinders the development of mass cultivation technology of this species. The objective of this work was to describe male-female interactions during mating of $O$. tehuelchus under controlled aquarium conditions.

Octopuses hatched in captivity at the Estación Experimental de Maricultura, Instituto Nacional de Investigación y Desarrollo Pesquero (INIDEP). They were maintained individually in 301 aquaria connected to a recirculation aquaculture system (RAS). Seashells were provided as individual shelters. Photoperiod was set at 12:12 h (light : dark). Water quality parameters were monitored daily and maintained at $15.5 \pm 1.1{ }^{\circ} \mathrm{C}$ (Earth
Industries heater/cooler, Japan), $\mathrm{pH} 7.7 \pm 0.2$ (Oakton pH/temperature Series110 RM232), salinity $34 \pm 1$ (Tanaka NewS-100 light refractometer), and total ammonia concentration $0.0 \pm$ $0.5 \mathrm{mg} \mathrm{NH}_{4}^{+} \mathrm{L}^{-1}$ (Merck colorimetric kit). Four pairs (male-female) of adult octopuses (ninemonth-old) were used to record the events during the mating courtship. Prior to weighting and handling, individuals were anesthetized with $2.5 \%$ ethyl alcohol in sea water, following bioethical guidelines by Fiorito et al. (2014) and ButlerStruben et al. (2018). Total weight was registered by using a Mettler Toledo PB 602-S. Initial weight range was $100-125 \mathrm{~g}$ and $38-48 \mathrm{~g}$ for females and males, respectively. Each couple was placed in an 801 aquarium with seashells and fed ad libitum with fresh shrimp (Artemesia longinaris). Male-female interactions were recorded during daytime hours. Mating behavior of Patagonian octopus was classified following the crite- 
ria proposed by Huffard et al. (2008), Rodrigues et al. (2009) and Caldwell et al. (2015), which were described as pre-copulatory (swimming, display, and contact) and copulatory behavior. Once the mating was over, male and female were left in the mating tank until the experience ended. After intercourse, females were sedated and examined to verify the presence of spermatophores in the distal oviducts. Octopus behavior in each aquarium was recorded and photographed daily with a Sony Lens G camera.

Three pre-copulatory events (male display, female display, and contact) and one copulatory behavior (intercourse) were observed. Male exhibited an intense and changing reddish color during the display, moving around female's shelter (Figure $2 \mathrm{~A}$ ) and also returning back to his own shelter. Female exhibited a pale and homogeneous coloration, remaining inside the shelter and displaying her arms outside and directs them towards the male (Figure 2 B). Contact event consisted of touching each other with one or more arms for short intervals of time (5-10") (Figure 2 C). During copulation male moved towards the female and partially or totally surrounded her with his arms (Figure 2 D). Female remained in her shelter exposing her oral surface with her arms folded towards her mantle while male performed the insemination process by intruding the hectocotylized arm into the female's mantle accompanied by occasional changes in body coloration patterns (Figure $2 \mathrm{E}$ and $\mathrm{F}$ ). The approximate duration of the copula was 3 to $5 \mathrm{~min}$. After that, male returned to his shelter. Copulation event was repeated 2 to 3 times during the same day, always preceded by the display of the female and the contact of the arms. Couples remained together (from a few days to weeks) in the same tank until female's aggressive behavior towards the male was observed, including the removal of male's shelters. Coincidently with this behavior, egg clutches were found in female's shelters in all cases and males were consequently removed from the mating tanks.
Courtship is an important mechanism in the couple's choice (Krebs and Davies 1993). Huffart et al. (2008) reported a pre-copulatory behavior characterized for a recognition interaction at species and sex level during the onset of courtship in Abdopus aculeatus. Gutierrez et al. (2012) indicated that a pre-copulatory behavior in Enteroctopus megalocyathus begun with the approach without physical contact followed by three consecutive events: swimming, exhibition and contact. In the present work, both male and female exhibited display behaviors, remarkable changes in coloration and contact between the arms, confirming that a pre-copulatory behavior was present.

Copulation mode and chromatic changes varies significantly in cephalopods (Mangold 1987; Hanlon and Messenger 1996). In squids like Sepioteuthis lessoniana and S. australis mating position is called 'head to head', where male holds the female with the arms (Boal and Gonzalez 1998). In sepiolids, however, the copulatory strategy observed is the so-called 'male to female neck', accompanied by intense color patterns characteristic for each sex (Moynihan 1983; Nabhitabhata et al. 2005; Rodrigues et al. 2009). Mangold (1987) observed two mating positions in specimens of Family Octopodidae: the 'distance position' in which male and female remain separated during the copulation (only joined by the hectocotyle), and the 'close position' in which the male rides the female. In both cases, the interactions can last from a few minutes to hours. Authors such as Hanlon and Messenger (1996) and Wells and Wells (1972), determined that copula positions in octopuses are of 'distance' or 'assembly', or an intermediate positions between the two. Oral surface of female O. tehuelchus faces out of the shelter while the mantle looks towards the eggs during parental care. This mating position was described previously as 'beak to beak' by Caldwell et al. (2015) for the Great Pacific Striped Octopus (LPSO). The same authors indicated that, unlike the 'distance' and 'assembly' positions observed in other types of 


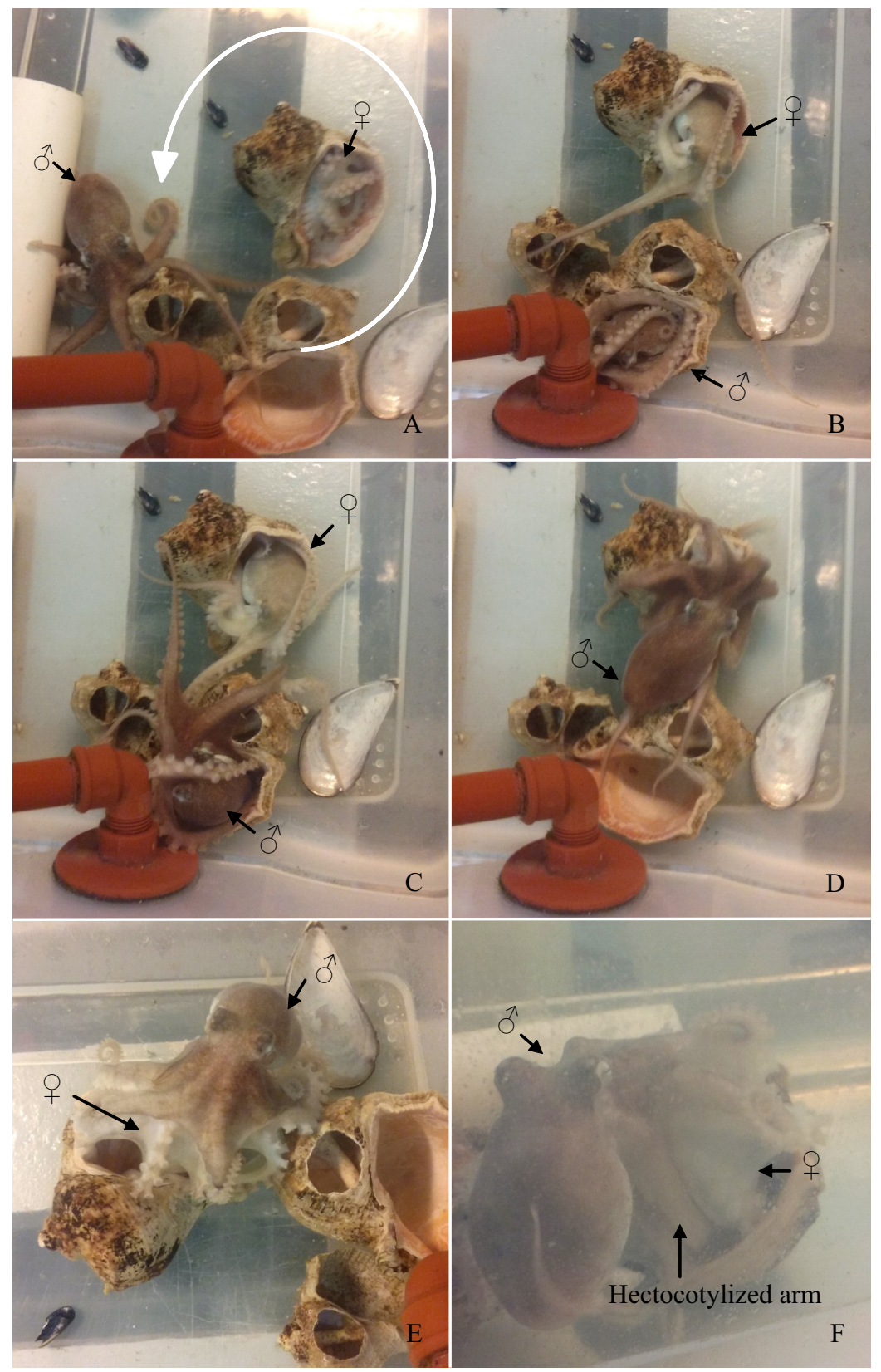

Figure 2. Detail of mating events of Patagonian octopus Octopus tehuelchus. Precopulatory behavior: male display (the arrow indicates the movement of the male) (A), female display (B), contact (C). Copulatory behavior: copula (D-F).

octopus, the 'beak to beak' mating implies an effective grip and allows a complete wrapping of the male over the female's oral region, as well as conferring specific advantages such as protection of eggs clutches by female. Generally, in octopuses that have other mating positions such as $O$. cyanea (Tsuchiya and Uzu, 1997), Vulcanoctopus hydrothermalis (Rocha et al. 2002), O. kaurna 
(Norman 2000) and O. bimaculoides (Hanlon and Messenger 1996) females can mate with several males simultaneously.

Although many aspects of the mating behavior of $O$. tehuelchus are similar to those reported for LSPO, including the 'beak to beak' mating position, it should be noted that female Patagonian octopus remains in the shelter during the pre-copula and copula events. The observations obtained during the present work showed complex behaviors between males and females during mating events, such as a protective behavior of the putting in parallel with the rejection of the already copulated male by female. In this sense, and from a zootechnical point of view, these data are highly relevant for the handling of specimens during reproductive conditioning of $O$. tehuelchus in the laboratory.

INIDEP contribution no. 2210.

\section{REFERENCES}

Berrueta M, Aristizabal Abud E, Ricci E, BocCANfuso J. 2018a. Avances en el desarrollo de tecnología de producción comercial de juveniles de pulpito Octopus tehuelchus 20162017. Inf Ases Transf INIDEP N ${ }^{\circ} 12 / 2018.15$ p.

Berrueta M, Radonic M, López A, Desiderio J, ORTIZ N. 2018b. Modelo predictivo para la evaluación del estatus reproductivo del pulpito Octopus tehuelchus mediante el uso de la técnica ecográfica. Inf Invest INIDEP $\mathrm{N}^{\circ}$ 110/2018. $16 \mathrm{p}$.

Boal JG, Gonzalez SA. 1998. Social behaviour of individual oval squids (Cephalopoda, Teuthoidea, Loliginidae, Sepioteuthis lessoniana) within a captive school. Ethology. 104: 161-178.

BoletZKy S, Hanlon RT. 1983. A review of the laboratory maintenance, rearing and culture of cephalopod molluscs. Mem Natl Mus Victoria.
44: 147-187.

Butler-Struben HM, BRophy SM, JOHNSON NA, CROOK RJ. 2018. In vivo recording of neural and behavioral correlates of anesthesia induction, reversal, and euthanasia in cephalopod molluscs. Front Physiol. 9: 109-112.

Caldwell RL, Ross R, Rodaniche A, Huffard CL. 2015. Behavior and body patterns of the larger Pacific striped octopus. PLOS ONE. 10 (8): e 0134152.

Fassiano A, Ortiz N, Ríos de Molina MC. 2017. Reproductive status, antioxidant defences and lipid peroxidation in Octopus tehuelchus (Cephalopoda: Octopodidae) females. J Nat Hist. 51: 2645-2660.

Fiorito G, Affuso A, Anderson DB, Basil J, Bonnaud L, Botta G, Cole A, D'Angelo L, De Girolamo P, Dennison N, Dickel L, et al. 2014. Cephalopods in neuroscience: regulations, research and the 3Rs. Invert Neurosc. 14: 13-36.

Gutiérrez R, Farías A, YANy G, Uriarte I. 2012. Interacciones macho-hembra del pulpo rojo patagónico Enteroctopus megalocyathus (Cephalopoda: Octopodidae) durante el comportamiento de apareamiento. Lat Am J Aquat Res. 40: 808-812.

Hanlon RT, Messenger JB. 1996. Cephalopod behavior. Cambridge: Cambridge University Press. 232 p.

Huffard CL, Caldwell RL, Boneka F. 2008. Mating behavior of Abdopus aculeatus (d'Orbigny 1834) (Cephalopoda: Octopodidae) in the wild. Mar Biol. 154: 353-362.

IRIBARNE O. 1991. Intertidal harvest of the Patagonian octopus, Octopus tehuelchus (d'Orbigny). Fish Res. 12: 375-390.

KREBS JR, DAVIES NB. 1993. An introduction to behavioural ecology. 3th ed. Oxford: Blackwell Scientific Publications. 420 p.

MANGOLD K. 1987. Reproduction. In: BoyLE PR, editor. Cephalopod life cycles: Volume II comparative reviews. London: Academic Press. p. 157-200. 
MOYNIHAN M. 1983. Notes on the behavior of Euprymna scolopes (Cephalopoda: Sepiolidae). Behaviour. 85: 25-41.

Nabhitabhata J, Nilaphat P, Promboon P, JAROONGPATTANANON C. 2005. Life cycle of cultured bobtail squid, Euprymna hyllebergi (Nateewathana, 1997). Phuket Mar Biol Cent Res Bull. 66: 351-365.

NARVARTe M, GonzÁlez R, Filippo P. 2007. Artisanal mollusk fisheries in San Matías Gulf (Patagonia, Argentina): An appraisal of the factors contributing to unsustainability. Fish Res. 87: 68-76.

NARVARTE M, GonzÁlez R, Fernández M. 2006. Comparison of tehuelchus octopus (Octopus tehuelchus) abundance between an openaccess fishing ground and a marine protected area: evidence from a direct development species. Fish Res. 79: 112-119.

Narvarte M, GonzÁlez R, Sica I. 1996. Estado actual de la pesquería de pulpito patagónico Octopus tehuelchus en el Golfo San Matías. Informes Técnicos del Plan de Manejo Integrado de la Zona Costera Patagónica, Puerto Madryn, Argentina. 19. 33 p.

Norman M. 2000. Cephalopods: a world guide. Hackenheim: ConchBooks. 318 p.

PujALs MA. 1982. Contribución al conocimiento de la biología de Octopus tehuelchus d'Orbigny (Mollusca: Cephalopoda). Acad. Nac. Cs. Serie I - Ciencias. 46: 30-71.

RÉ ME. 1998. Pulpos octopódidos (Cephalopoda: Octopodidae). In: Boschi EE, editor. El Mar Argentino y sus recursos pesqueros. Tomo 2. Los moluscos de interés pesquero. Cultivos y estrategias reproductivas de bivalvos y equinoideos. Mar del Plata: Instituto Nacional de Investigación y Desarrollo Pesquero (INIDEP). p. 69-98.

Ré ME. 2008. Cefalópodos. In: Boltovskoy D, editor. Atlas de sensibilidad del mar y la costa. http://geoportal.ddns.net/atlasambiental/index. htm.
RÉ ME, Ortiz N. 2011. Cefalópodos capturados en la Campaña "CONCACEN - Noviembre 2009”, B/O Puerto Deseado. VIII Congreso Latinoamericano de Malacología. Libro de resúmenes. p. 249.

Rocha F, González A, Segonzac M, Guerra A. 2002. Behavioural observations of the cephalopod Vulcanoctopus hydrothermalis. Cah Biol Mar. 43: 299-302.

Sims DW, NASh JP, MorritT D. 2001. Movements and activity of male and female dogfish in a tidal sea lough: alternative behavioural strategies and apparent sexual segregation. Mar Biol. 139: 1165-1175.

Rodrigues M, Garcí M, Guerra A, Troncoso J. 2009. Mating behavior of the Atlantic bobtail squid Sepiola atlantica (Cephalopoda: Sepiolidae). Vie et Milieu. 59: 271-275.

Storero LP, NARVArte M, GonzÁlez RA. 2012. Reproductive traits of the small Patagonian octopus Octopus tehuelchus. Helgol Mar Res. 66: 651-659.

Storero LP, OcAmpo-Reinaldo M, GonzÁlez RA, NARVARTE M. 2010. Growth and life span of the small octopus Octopus tehuelchus in San Matías Gulf (Patagonia): three decades of study. Mar Biol. 157: 555-564.

TSUCHIYA K, UzU T. 1997. Sneaker male in octopus. Venus Jap J Malacol. 56: 177-181.

Wells MJ, Wells J. 1972. Sexual displays and mating of Octopus vulgaris Cuvier and $O$. cyanea Gray and attempts to alter performance by manipulating the glandular condition of the animals. Anim Behav. 20: 293-308.

Wood JB, Kenchington E, O’Dor RK. 1998. Reproduction and embryonic development time of Bathypolypus arcticus, a deep-sea octopod (Cephalopoda: Octopoda). Malacología. 39: 11-19.

Received: 15 January 2020 Accepted: 3 February 2020 